Relations industrielles

Industrial Relations

\title{
Illégalité de la formule Rand
}

\section{Cour d'appel}

Volume 13, numéro 1, janvier 1958

URI : https://id.erudit.org/iderudit/1022467ar

DOI : https://doi.org/10.7202/1022467ar

Aller au sommaire du numéro

Éditeur(s)

Département des relations industrielles de l’Université Laval

ISSN

0034-379X (imprimé)

1703-8138 (numérique)

Découvrir la revue

Citer ce document

Cour d'appel (1958). Illégalité de la formule Rand. Relations industrielles / Industrial Relations, 13(1), 62-75. https://doi.org/10.7202/1022467ar
Résumé de l'article

Dans un jugement de la Cour du banc de la Reine (juridiction d'appel), six juges décident à l'unanimité de confirmer la décision du juge Fernand Choquette, de la Cour supérieure, rendue à Québec le 7 septembre 1956, et selon laquelle est illégale la clause de retenue syndicale dite " formule Rand » qui vise même les employés non syndiqués. Cette cause est portée en appel devant la Cour Suprême.
Tous droits réservés @ C Département des relations industrielles de l’Université Laval, 1958
Ce document est protégé par la loi sur le droit d'auteur. L’utilisation des services d'Érudit (y compris la reproduction) est assujettie à sa politique d'utilisation que vous pouvez consulter en ligne.

https://apropos.erudit.org/fr/usagers/politique-dutilisation/ 


\title{
JURISPRUDENCE DU TRAVAIL
}

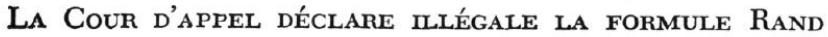

\begin{abstract}
Dans un jugement de la Cour du banc de la Reine ${ }^{1}$ (juridiction d'appel), six juges décident à l'unanimité de confirmer la décision du juge Fernand Choquette ${ }^{2}$, de la Cour supérieure, rendue à Québec le 7 septembre 1956, et selon laquelle est illégale la clause de retenue syndicale dite «formule Rand》 qui vise même les employés non syndiqués. Cette cause est portée en appel devant la Cour Suprême.
\end{abstract}

Voici les notes intégrales des $\operatorname{six}^{3}$ juges.

\section{JUGE PRATTE}

Aux termes d'une convention collective intervenue entre la Compagnie $\mathrm{Pa}$ quet Ltée et le Syndicat Catholique des employés de magasins de Québec Inc., l'employeur a pris l'engagement de retenir sur le salaire de ses employés un montant égal à la cotisation fixée par le syndicat pour ses membres et de remettre à celui-ci la somme ainsi prélevée.

Les six cent sept employés visés par la convention ayant été informés de cette stipulation, quelque deux cent cinquante d'entre eux, n'appartenant pas au syndicat, donnèrent avis à l'employeur qu'ils ne consentaient pas à cette retenue. L'employeur fit part au syndicat de l'opposition de ces employés, ajoutant qu'il continuerait néanmoins à faire la retenue, mais qu'il déposerait à un compte de banque spécial les montants pris sur le salaire des opposants, jusqu'à ce que l'objection élevée par ces employés ait été décidée en manière prévue dans la convention. L'employeur et le syndicat entreprirent ensuite de faire régler le différend conformément aux dispositions de l'entente, mais avant que n'ait été constitué le conseil d'arbi-

(1) Jugement rendu le 27 décembre 1957 par les honorables juges Galipeault, Pratte, Casey, Hyde, Taschereau et Owen, Cour du Bane de la Reine (juridiction d'appel), District de Québec, no 5270.

Le Syndicat catholique des Employés de Magasins de Québec, Inc., (Demandeur) - Appelant, vS La Compagnie Paquet Ltêe, (Défenderesse) - Intimée.

(2) On en trouve le texte intégral dans Relations Industrielles, numéro de juillet 1957, volume 12. numéro 3 , pages 244-251.

(3) On n'a pas utilisé les notes de l'honorable juge McDougall, décédé récemment. trage prévu dans cet accord, le syndicat, (qui, vraisemblablement, croyait devoir agir en justice avant l'expiration du délai de six mois fixé par larticle 26 de la Loi des syndicats professionnels pour l'exercice des recours nés de la convention collective) intenta à l'employeur l'action qui nous est soumise, pour se faire payer trois mille dollars $(\$ 3,000.00)$, qui serait la somme des montants jusqu'alors retenus aux employés protestataires.

La défenderesse a opposé quatre moyens de défense: 1) elle aurait été forcée de signer la convention, à la suite d'un arrêt de travail illégalement provoqué par le demandeur; 2) la Commission des relations ouvrières aurait refusé d'enregistrer la convention; 3) le demandeur aurait refusé de soumettre le différend à l'arbitrage, au mépris d'une clause de l'entente; et 4) la stipulation invoquée par le demandeur (clause 2.01 de la convention) ne serait pas permise par la loi. Quant à ce dernier moyen, la défenderesse l'a aussi fait valoir par demande reconventionnelle, pour faire prononcer la nullité de la stipulation. A ce sujet, il convient d'observer que si la défenderesse n'a pas demandé l'annulation de toute la convention, c'est que les parties étaient convenues (clause 16.01) que l'invalidité de l'une quelconque de leurs stipulations n'aurait pas pour effet d'entraîner la nullité de toute l'entente.

Le juge de première instance a disposé de tous les moyens de la défenderesse, mais n'en a retenu qu'un: il a conclu à la nullité de la clause 2.01 et. prononçant en conséquence, il a débouté le demandeur et fait droit à la demande reconventionnelle.

C'est ce jugement qui est frappé d'appel par le syndicat. 
De toute évidence, si la stipulation invoquée par le demandeur n'est point valide, il serait inutile d'examiner les autres moyens de la défenderesse. Aussi, il me paraît que c'est ce point-là qu'il faut examiner d'abord.

La clause en question est l'une de celles dites de sécurité syndicale, qui visent à accroître la puissance des syndicats; c'est celle qui est communément appelée la formule Rand, du nom de l'éminent magistrat qui a eu recours à ce moyen, en 1945 , pour mettre fin à un différend ouvrier dont il avait été nommé le seul arbitre. Suivant ce que l'on dit, elle serait justifiée du fait que la convention collective ne profite pas qu'aux seuls membres du syndicat qui l'a conclue, mais à tous les employés visés par cette entente. Dès lors que tous vont tirer avantage de la convention, il serait juste, dit-on, que tous soient tenus d'apporter une aide pécuniaire au syndicat qui l'a conclue et sur qui retombent les dépenses qu'entraînent la négociation de l'accord et la surveillance de son exécution.

Voici le texte de cette stipulation:

«2.01 - L'employeur retiendra sur la paie ( sic) de chaque employé régulier assujetti à la présente convention, une somme égale à la cotisation fixée par le syndicat pour ses membres, et remettra dans les dix premiers jours du mois suivant. au représentant autorisé du syndicat, le prélèvement ainsi perçu. »

L'appelant fonde son appel sur le principe de la liberté des conventions, que reconnaît l'article 21 de la loi des syndicats professionnels (S.R.Q. 1941, ch. 162). La stipulation précitée n'étant prohibée par aucun texte, dit-il, elle doit être tenue pour valide.

S'agissant de convention collective, c'est dans les lois qui régissent cette espèce de convention qu'il faut chercher la solution du litige. Mais avant que d'entreprendre cette recherche, il paraîtrait utile de retracer brièvement l'évolution de notre droit en cette matière.

Sous le droit commun, les conditions du contrat de travail sont établies de gré à gré, après discussion entre employeur et employé. Mais le développement du commerce et de l'industrie ayant fait apparaître que ces rapports individuels sont souvent loin d'être équitables pour l'employé, un régime de rapports collectifs a été préconisé comme moyen propre à améliorer le sort des travailleurs.

C'est ainsi qu'en 1924 le législateur, qui adoptait alors la loi des syndicats professionnels (S.R.Q. 1941, ch. 162), a été amené à édicter les articles 21 à 26 , concernant la convention collective. Le premier de ces articles définit la convention collective et précise que peuvent faire l'objet d'une telle convention «tous les engagements concernant les conditions du travail qui ne sont pas défendus par la loi »; le second, lui, dit quelles personnes sont liées par cette convention. $\mathrm{Si}$ on lit ces dispositions, on voit tout de suite que la convention envisagée par cette loi en est une librement négociée par l'employeur et qui, en définitive, ne lie que les employés faisant partie du groupement qui l'a signée.

En 1940, la législature adoptait la Loi de la convention collective (4 Geo. VI, ch. 38, qui forme le chapitre 163 des S.R.Q. 1941), dont toutes les dispositions sont assorties au seul dessein de permettre au lieutenant-gouverneur en conseil de décréter l'extension juridique de la convention. Cette loi ne contenant aucune disposition qui soit pertinente à notre litige, il n'y a pas lieu de nous y arrêter.

Quatre ans plus tard, soit en 1944, la convention coliective étant définitivement entrée dans nos moeurs, la législature a édicté la Loi des relations ouvrières ( $8 \mathrm{Geo}$. VI, ch. 30 , qui constitue le chap. 162A des S.R.Q. 1941), qui établit, pour la convention collective, un régime tout à fait différent du premier.

Sous cette nouvelle loi, le groupement de salariés qui réunit la majorité absolue des employés d'un établissement ne représente plus seulement ceux qui le composent, comme c'était le cas auparavant, mais tous les employés, et la convention n'est plus un acte purement facultatif de la part de l'employeur. En effet, aux termes de l'article 4, «tout employeur est tenu de reconnaître comme représentant collectif des salariés à son emploi les représentants d'une association groupant la majorité absolue des dits salariés et de négocier, de bonne 
foi, avec eux, une convention collective de travail ». Si les parties en présence ne s'entendent pas, l'une ou l'autre peut donner avis du désaccord à la Commission de relations ouvrières, qui en informe le ministre du travail et celui-ci désigne un conciliateur (arts. 12 et 13.) $\mathrm{Si}$ ce dernier échoue, le ministre nomme un conseil d'arbitrage. Et tant qu'il ne s'est pas écoulé quatorze jours depuis la réception par le ministre du travail, du rapport du conseil d'arbitrage, toute grève ou contre-grève (lock-out) est interdite et l'employeur ne doit pas changer les conditions de travail de ses salariés sans leur consentement (art. 24).

Ici, il y a lieu d'observer que si l'employeur n'est pas tenu de conclure une convention, sa liberté de s'en abstenir est tout de même singulièremetn diminuée, du fait que la loi l'oblige à négocier de bonne foi (sous peine d'amende) et que, si les négociations échouent, il est exposé aux conséquences d'une grève.

Notons enfin que la même loi reconnaît à l'ouvrier la liberté de faire partie du syndicat de son choix ou de n'appartenir à aucun et qu'elle édicte des sanctions contre toute personne usant «d'intimidation ou de menaces pour amener quiconque à devenir membre, à s'abstenir de devenir membre ou à cesser d'être membre d'une association》 (art. 22).

Or, c'est sous le régime établi par cette loi (S.R.Q. 1941, ch. 162A) qu'a été conclue, à la suite d'un arrêt de travail, la convention qui a donné lieu à ce procès. Aussi, il paraît clair que la question en litige ne peut être décidée sans égard aux dispositions que je viens de signaler.

Ces préliminaires posés, venons à la clause en litige, dont j'ai déjà reproduit le texte.

Cette stipulation fait naître en faveur du syndicat un droit de créance dirigé seulement contre l'employeur. Mais à moins que oelui-ci ne veuille payer luimême, sous forme de dommages-intérêts, les cotisations exigées par le syndicat, il ne pourra avoir à son service que des personnes qui consentent à reroncer à une partie de leur salaire en faveur du syndicat. Cela revient à dire que cette clause aura presque nécessairement pour effet de limiter le droit d'embauchage de l'employeur, de porter atteinte à la liberté de ceux qui voudraient prendre de l'emploi chez l'intimée et de faire perdre à ceux des employés qui n'appartenaient pas au syndicat lors de la signature de la convention la chance qu'ils avaient de voir se prolonger la durée de leur emploi, à moins que ces employés ne consentent à verser une cotisation à un syndicat auquel ils ne sont pas tenus d'appartenir. Et tout cela, dans le seul intérêt du syndicat, pour lui assurer des cotisations qu'il n'aurait pas le droit de réclamer directement.

Comme il a déjà été dit, l'appelant fonde son appel sur le principe de la liberté des conventions, que reconnaît expressément le dernier alinéa de l'article 21 de la Loi des syndicats professionnels, ci-après récité:

$$
\ll 21 \ldots
$$

«Peuvent faire l'objet d'une convention collective de travail, tous les engagements concernant les conditions du travail qui ne sont pas défendus par la loi.»

Dès lors, dit-il, que la stipulation contenue dans la clause 2.01 n'est prohibée par aucun texte, il faut la tenir pour valide.

Or, la disposition ci-dessus reproduite ne dit pas que peuvent faire l'objet d'une convention collective tous les engagements qui ne sont pas défendus, mais seulement ceux de ces engagements qui concernent «les conditions de travail ». Par conséquent, et et: égard seulement à la disposition précitée, le litige ne pose pas seulement la question de savoir si l'engagement pris par l'intimée est défendu par la loi: il présente d'abord à décider si cet engagement porte sur une condition de travail. Quant à la loi des relations ouvrières (S.R.Q. 1941 ch. 162A), sous le régime de laquelle la convention a été conclue, elle ne permet pas de conclure autrement. Il est vrai que cette loi ne contient pas de disposition semblable au dernier alinéa de l'article 21 de la loi des syndicats professionnels; mais cela est sans importance, vu que la convention collective $y$ est définie (art. 2e) comme «une entente ... relative 
aux conditions de travail ».

L'appelant soutient encore qu'un employeur étant libre d'embaucher qui il désire, et tous les employés visés par la convention pouvant être renvoyés sans avis (selon les termes de leur contrat d'engagement), rien ne s'opposait à l'engagement que l'on connaît; et que l'intimée s'étant ainsi obligée, elle doit être tenue de s'exécuter, même si le syndicat n'avait pas le pouvoir de lier d'autres employés que ses membres.

En posant ainsi la question, l'appelant laisse de côté l'élément le plus important du problème: celui qui résulte de ce que l'engagement dont il demande l'exécution n'a pas été pris dans un contrat librement conclu sous le droit commun, mais dans une convention collective conclue sous le régime de la loi des relations ouvrières. Or, les dispositions de cette loi qui obligent l'employeur à négocier une convention collective et à se soumettre à l'arbitrage n'ont pas été édictées pour l'amener à prendre n'importe quel engagement, au choix du syndicat: elles sont destinées uniquement à favoriser la conclusion d'une convention «relative aux conditions de travail» (S.R.Q. 1941, ch. $162 \mathrm{~A}$, art. 2e).

Par où l'on voit que le moyen que l'appelant tire du principe de la liberté des conventions ne touche pas au roeud du litige, qui est de savoir si l'engagement pris par l'intimée est de ceux envisagés par la loi des relations ouvrières comme pouvant faire l'obiet d'une convention collective. En d'autres termes, il faut voir si cet engagement porte sur une condition de travail.

Les mots «conditions de travail» pouvant être pris dans un sens plus ou moins étendu selon l'idée ou l'intérêt de celui qui les emploie et la loi ne contenant aucune disposition expresse qui délimite autrement le champ de la convention collective, il faut rechercher lintention du législateur. Celui-ci a-t-il voulu laisser aux signataires une entière liberté à cet égard. sans autre limite que celle résultant des lois prohibitives, ou a-t-il entendu que le domaine de la convention fût autrement circonscrit? C'est ce qu'il faut chercher, en tenant compte à la foi du but visé par le législateur, des indices que la loi peut contenir sur le point qui nous intéresse et des présomptions qui s'imposent à l'interprète. Et parmi ces présomptions, il y a celles, bien connues, que le législateur n'a pas voulu accorder plus de droits ou de pouvoirs qu'il n'est nécessaire pour assurer l'exécution de sa volonté, ni modifier sans nécessité des situations préexistantes, de droit ou de fait.

Traitant des termes généraux employés par le législateur, voici ce qu'on lit dans Maxwell (Interpretation of Statutes, 9e édit., pp. 85-86), qui cite des autorités à l'appui de ses propositions:

« Presumption against Implicit Alteration of Law»:

«One of these presumptions is that the Legislature does not intend to make any substantial alteration in the law beyond what it explicitly declares, either in express terms or by clear implication, or, in other words, beyond the immediate scope and object of the statute. In all general matters outside those limits the law remains undisturbed. It is in the last degree improbable that the Legislature would overthrow fundamental principles, infringe rights, or depart from the general system of law, without expressing its intention with irresistible clearness, and to give any such effect to general words, simply because they have a meaning that would lead thereto when used in either their widest, their usual, or their natural sense, would be to give them a meaning other than that which was actually intended. General words and phrases, therefore, however wide and comprehensive they may be in their literal sense, must, usually, be construed as being limited to the actual objects of the Act. The general words of the Act are not to be so construed as to alter the previous policy of the law. In construing the words of an Act of Parliament we are justified in assuming the Legislature did not intend to go against the ordinary rules of law, unless the language they have used obliges the Court to come to the conclusion that they did so intend. 》

C'est donc en tenant compte de ces règles d'interprétation qu'il faut chercher si l'engagement de l'intimée porte sur une «condition de travail ». 
La loi des relations ouvrières adoptée sous le titre de «Loi concernant les relations entre employeurs et employés » ( 8 Geo. VI, ch. 30 ) a été édictée pour réglementer la convention collective, qui est destinée à mettre l'employé en état d'obtenir de l'employeur un contrat de travail plus équitable que celui qu'il pourrait conclure à la suite d'une discussion individuelle. Or, tout ce qui est requis pour que l'employé puisse profiter des avantages que le régime des rapports collectifs est destiné à lui apporter, c'est que les parties à la convention soient admises à stipuler sur tout ce qui peut faire l'objet des relations entre employeur et employé, notamment les prestations réciproques des parties au contrat de travail, les modalités dont ces prestations sont susceptibles d'être affectées et le mode d'exercice des droits des parties au contrat. Il n'est surtout pas nécessaire, pour la réalisation de la fin visée par le législateur, que l'employeur et les représentants des employés puissent s'entendre pour subordonner la formation du contrat de travail à l'accomplissement d'une condition qui, n'ayant aucun rapport avec le contenu de ce contrat, vise seulement à promouvoir l'intérêt du syndicat aux dépens d'une partie des ouvriers. Aussi, et à moins de trouver dans la loi quelque disposition qui manifeste, expressément ou implicitement, l'intention de permettre une stipulation comme celle qui nous intéresse, je dirais que telle stipulation ne peut pas faire l'objet d'une convention collective.

Or, non seulement la loi ne contient aucune telle manifestation de volonté, mais on n'y trouve rien qui permette d'induire que le législateur ait même seulement envisagé l'aménagement, dans la convention collective, de rapports contractuels quelconques au profit du syndicat.

Mais l'apppelant soutient que, la convention collective pouvant embrasser toutes les relations entre employeur et employés, il n'est pas possible que le législateur ait entendu en limiter le domaine de manière à exclure tout le champ d'action des organismes formés pour la conclure. Et à l'appui de cette prétention, il invoque l'arrêt de cette Cour dans la cause de Price Brothers vs Letarte (1953) B.R. p. 307.

Disons tout de suite, au sujet de ce jugement, que la clause litigieuse ne visait pas à rendre le paiement de la cotisation syndicale obligatoire pour tous les employés (comme c'est le cas dans l'espèce qui nous occupe) mais seulement à obliger l'employeur à retenir la cotisation des employés qui y consentiraient, et cela seulement aussi longtemps quils le voudraient. Il faut observer aussi que seulement deux des quatre juges formant la majorité de la Cour ont prononcé la validité de la clause en question, les deux autres étant d'opinion de rejeter l'appel par un autre motif. D'où l'on voit que l'arrêt en question n'a rien décidé qui puisse influer sur la solution du présent litige.

Quant à la prétention de l'appelant, il me paraît nécessaire, pour en disposer, de voir quel est le rôle que la loi attribue au syndicat dans la formation de la convention collective.

Que l'on prenne la loi des syndicats professionnels ou la loi des relations ouvrières, l'on voit que le syndicat qui conclut une convention collective n'agit pas pour lui-même, mais à titre de représentant. Dans le premier cas, il représente seulement ses membres; dans le second, il représente tous les employés, son pouvoir d'agir pour ceux qui ne sont pas de ses membres lui étant donné par la loi. Or, celui à qui la loi accorde le pouvoir d'agir pour autrui dans la passation d'un acte juridique ne peut pas utiliser ce pouvoir pour ses fins personnelles et au détriment des intérêts qu'il a mission de représenter et de servir, les principes étant que le pouvoir de représentation est conféré dans l'intérêt du représenté, non du représentant, et que les pouvoirs que la loi accorde ne doivent pas être exercés pour une fin autre que celle à laquelle ils sont ordonnés. Dans le cas d'une convention collective, ces principes s'imposent d'autant plus que, par l'effet de l'article 4 de la Loi des relations ouvrières, la qualité de représentant comporte un certain pouvoir de coercition sur l'employeur. Aussi paraît-il clair que la nature même du rôle que la loi attribue au syndicat dans la formation de la convention collective (que cette convention soit ou non un contrat, ce sur quoi il n'y a pas lieu de prononcer) s'oppose à ce que celui-ci stipule de l'employeur un engagement comme celui que l'appelant a obtenu de l'intimée. Pour décider autrement, il faudrait pouvoir pré- 
sumer que la législature a entendu permettre au représentant des employés d'utiliser contre un certain nombre de ceux-ci et à son profit l'arme puissante dont elle lui a confié l'usage dans l'intérêt de tout. Or, cela n'est pas possible dans l'état actuel de notre droit.

Certes, l'on peut bien penser, dans l'état actuel des choses, qu'il serait juste que tous les employés régis par une convention collective fussent tenus de contribuer aux dépenses encourues pour négocier cette entente et en assurer l'exécution, et qu'une législation qui ne permet pas cette mesure d'équité ne répond pas tout à fait aux besoins de l'heure. Mais c'est là l'affaire du législateur.

Je conclurais donc, comme le juge de première instance, que l'engagement dont l'appelant demande l'exécution ne porte pas sur une condition de travail et, partant, qu'il pouvait faire l'objet d'une convention collective et doit être tenu pour invalide. En conséquence, je rejetterais l'appel avec dépens.

\section{JUGE HYDE}

This is an appeal from a judgment of the Superior Court, District of Quebec, dated September 7th, 1956, dismissing Appellant's action for the recovery of sums withheld by the Respondent from the wages of certain of its employees under the terms of a clause contained in a collective labour agreement between them and maintaining Respondent's cross-demand to declare such clause, based on what is generally known as the "Rand formula", null and void.

The jugdment appealed from disposed of other issues adversely to the Respondent, but if it was correct on the main issue of the disputed clause it will not be necessary to consider them. I propose, therefore, to deal first with that question and only such parts of the record as may be necessary to do so.

The Appellant union is incorporated under the Professional Syndicates' Act S.R.Q. 1941, Chap. 162 and received recognition under the Labour Relations Act, S.R.Q. 191, Chap. 162A, on December $6 \mathrm{th}, 1950$ as collective bargaining representative of Respondent's regular employees numbering 607 in all.
On March 24th, the parties signed a collective labour agreement for a period of two years.

Article II of this agreement provides as follows -

\section{ARTICLE II}

\section{REGIME SYNDICAL}

2.01 - L'employeur retiendra sur la paie de chaque employé régulier assujetti à la présente convention, une somme égale à la cotisation fixée par le syndicat pour ses membres, et remettra dans les dix (10) premiers jours du mois suivant, au représentant autorisé du syndicat, le prélèvement ainsi perçu.

\subsection{2 - Tous les employés régis par} la présente convention qui sont membres du syndicat, ou qui le deviendront, devront, comme condition du maintien de leur emploi, en demeurer membres pour la durée de la convention.

2.03 - Si un employé cesse d'être membre du syndicat, alors que conformément au paragraphe précédent il devrait y demeurer, le secrétaire du syndicat en donnera avis par écrit à l'employeur, et dans les quinze (15) jours suivants l'employeur devra mettre fin à l'emploi de l'employé à moins que, avant l'expiration đe ce délai, lemployé ait été réinstallé comme membre du syndicat.

2.04 - L'employeur permettra d'afficher sur les tableaux à cet usage les avis du syndicat à ses membres pourvu que ces avis aient été, au préalable, approuvés par l'employeur. »

On April 6th, 1955 a notice, signed bv Appellant's secretary-treasurer, was distributed by Respondent to the 607 employees covered by the agreement advising them of the terms of Article 9 of the by-law "fixant la cotisation syndicale de nos membres pour fin d'application de la Formule Rand" at fifty cents a week and that deductions therefor would commence on April 8th. This article 9 reads -

\section{“ARTICLE 9: Cotisation:}

a) La cotisation des membres est fixée à cinquante 0.50 sous par se- 
maine. Cette cotisation pourra être modifiée après avis de motion, par la majorité des membres présents à une assemblée régulière ou spéciale."

The court below, on the basis of admissions and documents in the record, found to the satisfaction of both parties -

b) Des 607 employés assujettis à la convention, 230 ont expressément autorisé la défenderesse à faire la retenue de leur cotisation syndicale et d'en faire remise au syndicat demandeur, 123 n'ont rien dit, et 254 ont adressé à la défenderesse l'écrit suivant en date du 22 avril 1955 ou des jours suivants:

“Je soussigné, déclare par la présente que je n'autorise pas La Compagnie Paquet Limitée à retenir sur mon salaire hebdomadaire la somme de $\$ 0.50$ en application de la "formule Rand" d'ici la fin du présent contrat."

Sauf une ou deux exceptions (non identifiées), les signataires de ces avis ne sont pas membres du syndicat demandeur.

c) Sur réception de cet écrit, la défenderesse a cessé de remettre au demandeur les sommes retenues sur le salaire des 254 signataires et elle les a déposées dans un compte de banque spécial en attendant le règlement du différend. Ce sont ces sommes que le demandeur réclame, soit, à la date de l'action, $\$ 2435.00$."

Arbitration was commenced in the hope of settling the dispute but before a conclusion was reached, Appellant instituted action on September 13th, 1955, against Respondent for $\$ 3,000.00$ then allegedly representing the amount withheld under the disputed clause, denied liability and by cross-demand asled that it (clause 2.01 of Art. II of the collective agreement above reproduced) be declared null and void and the agreement modified accordingly as provide in clause 16.01 thereof. The action was dismissed with costs and the cross-demand maintained but without costs as being unnecessary, conclusions as to nullity being receivable in defence to the principal action.
The "Rand formula" provides one of the recognized forms of union security, others being the union shop, the closed shop, maintenance of membership, and various types of check-off. The Rand formula was designed by Mr. Justice Rand, acting as arbitrator, as a solution to a crippling labour dispute in the Ford Motor Company plants in Ontario some ten years ago. (Labour Gazette, January 1946). The theory behind it is that the union acts as the bargaining representative of the whole group of employees it represents, whether members of the union or not, and that it is only fair and equitable that all those represented should contribute to the expense of maintaining that representation. The formula devised, as reproduced in the clause here in dispute (2.01), has the effect of requiring all employees in the bargaining unit, whether members or not, to pay the regular union dues throughout the term of the collective agreement.

The Federal Industrial Relations Act (R.S.C. 1952, ch. 153) specifically permits union security provisions in collective agreements (c.f. sec. 6, (1) and the Ontario Labour Relations Act, R.S.C. 1950 , ch. 194, expressly provides for a clause of the Rand formula type. Sec. 33 of that Act states that the parties may include in a collective agreement provisions -

“a) for requiring, as a condition of employment, membership in the trade union that is a party to or is bound by the agreement of granting a preference of employment to members of such trade union, or requiring the payment of dues or contribution to such trade union."

It is significant that there is no such provision in the Labour Relations Act of this Province. The only case dealing with any type of union security clause which this Court has had to consider was Price Bros. -vs- Letarte, 1953, Q.B. 307. It provided for a voluntary revocable check-off of union dues from the pay of union members only. Two members of the Court did not deal with the clause, deciding the appeal on other grounds. Of the other three Judges, of whom I was one, two - Mr. Justice Gagné and myself - approved the inclusion of the clause as a "condition of employment" or "condition de travail" 
under the Act and one, Mr. Justice Barclay, did not. Whichever view is accepted, and I have seen no reason to change my own, there is a most important distinction between the clause in that case and the one in this, a distinction in union security which I ervisaged at the time and noted in my opinion (pp. 312 and 314).

In that case we were dealing with a provision that made payment of union dues by the check-off method optional at all times to the employee and it could be said that it was in the interest of the employee so optating to ensure the maintenance of his membership in this way, even though it might at the same time be of considerable assistance to the union. Approval of such a voluntary check-off sanctioned no kind of coercion, but accepted it as a stipulation relating to the manner of payment of wages.

Under the Rand formula the employee has no option; in order to obtain his employment he must pay the dues of the union whether he is a member or not. If he is not a member of the union, as many are nor in this case, the collective agreement is made not by a representative designated by him but by one designated by the Labour Relations Act.

This being the case, the union's authority must be found in the Act and, as I have already indicated there is no express authority in this statute. Appellant contends, however, that it is implied as a "condition of employment" or "condition de travail" in the definition of "Collective Agreement" therein (sec. 2 (e) ) and would find in views expressed ir. Price Bros. -vs- Letarte (supra) support for this contention. Those views. however, were, as I have just noted, concerned with a voluntary revocable "check-off" of union dues permitting the employee, so optating, to have his employer pay his dues on his behalf, instead of remitting them himself whenever they became due, a procedure of evident advantage to the employee. Such a deduction is similar to other deductions made by many employers with the approval of the employee, for savings bonds, charitable contribution, insurance plans and the like and can be considered as relating to the manner of payment of the employee's wages.
While the present clause also provides for payment of union dues by deduction from wages and to that extent may be valid, it does something else for which no similar justification can be advanced, namely, it effectively requires non-union members to pay these dues without any agreement on their part to do so, a matter which is for the sole benefit of the union.

The Rand formula may be justly conceived on the equitable principle that each employee should share in the cost of collective bargaining, but the fact remains that it amounts to a compulsory payment in the nature of a tax which, in the absence of universal consent, must be based on some statutory authority. Not only is this lacking but, as the tearned Trial Judge pointed out, the clause in question infringes section 17 of the Professionnal Syndicates Act which governs the Appellant union. It states that -

"The members of a professional syndicate may resign voluntary without prejudice to the syndicate's right to claim the assessment for the three months following such resignation. They shall not be personally liable for the debts of the syndicate.

The syndicate shall not claim from a member ceasing to adhere thereto the assessment of more than three months."

The fact that the Respondent, as employer, has undertaken to withhold these sums from the wages of its employees does not, in my view render it personally liable if the stipulation itself is one which may not be made in a collective agreement. The negotiation of such an agreement is governed by the particular rules of the statute and it would obviously be improper to extend its special sanctions to matters not contemplated therein.

I am, therefore, of the opinion that the Court below was correct in its conclusion that -

"CONSIDERANT, sur le tout, que la défenderesse est bien fondée à conclure la nullité de la clause 2.01, telle que rédigée; qu'il y a cependant lieu de donner effet à la clause 16.01 précitée et de déclarer ladite clause modifiée de façon à se lire 
comme si la retenue prévue y était déclarée volontaire et révocable de la part des employés soumis à la convention (ce qui ne signifie pas que les parties n'auraient pu la stipuler irrévocable pour une période légale déterminée); que, vu le refus des 254 employés susdits de consentir à ladite retenue, la défenderesse est, aussi, bien fondée à demander le rejet de l'action."

This being my view I do not find it necessary to examine any of the other points raised by Respondent, I would accordingly dismiss this appeal with costs.

\section{JUGE TASCHEREAU}

Les faits ont été exposés ailleurs. Cependant, il m'est nécessaire de les résumer ici pour l'intelligence de ce qui va suivre.

Le 24 mars 1955, les parties ont conclu une convention collective dont l'article II se lit comme suit:

(D.C. 30 et 32 )

\section{ARTICLE II}

\section{REGIME SYNDICAL}

2.01 - L'employeur retiendra sur la paie de chaque employé régulier assujetti à la présente convention, une somme égale à la cotisation fixée par le syndicat pour ses membres, et remettra dans les dix. (10) premiers jours du mois suivant, au représentant autorisé du Syndicat, le prélèvement ainsi perçu.

2.02 - Tous les employés régis par la présente convention qui sont membres du Syndicat, ou qui le deviendront, devront, comme condition du maintien de leur emploi, en demeurer membres pour la durée de la convention.

\subsection{3 - Si un employé cesse d'être} membre du Syndicat alors que conformément au paragraphe précédent il devrait y demeurer, le secrétaire du Syndicat en donnera avis par écrit à l'employeur, et dans les (15) jours suivants l'employeur devra mettre fin à l'emploi de l'employé à moins que, avant l'expiration de ce délai, l'employé ait été réinstallé comme membre du Syndicat.
Quelque temps après, soit le 6 avril 1955 , tous les employés de l'intimée, au nombre de 607, étaient informés par le secrétaire du syndicat appelant que la cotisation syndicale prévue à la convention collective s'élèverait à $\$ 0.50$ par semaine, et que ce montant serait déduit de leur salaire, chaque semaine, à compter du 8 avril suivant. C'est alors que, sur les 607 employés régis par la convention collective, 254 ont écrit à l'intimée pour lui interdire de faire, en ce qui les concernait, aucune retenue syndioale. Malgré ces protestations, la Compagnie Paquet a continué à faire la retenue syndicale à même le salaire des ouvriers protestataires. Mais au lieu de remettre à l'appelant la somme d'argent ainsi recueillie, l'intimée l'a déposée dans un compte de banque en attendant le règlement du différend. Invoquant la convention collective, l'appelant a alors poursuivi l'intimée pour lui réclamer $\$ 3,000.00$ qui représenterait le montant total des cotisations perçues par la défenderesse pour le compte du syndicat.

Plusieurs moyens ont été soulevés par les parties. Toutefois, la question fondamentale est la suivante:

Un ouvrier peut-il être obligé par les termes d'une convention collective de travail de verser une cotisation à un syndicat dont il n'est pas membre?

Il est une règle bien connue c'est qu'on ne peut en son propre nom promettre que pour soi-même. Cette règle est édictée par l'article 1028 C.C.:

«Art. 1028. - On ne peut, par un contrat en son propre nom, engager d'autres que soi-même et ses héritiers et représentants légaux; mais on peut en son propre nom promettre qu'un autre remplira une obligation, et dans ce cas on est responsable des dommages, si le tiers indiqué ne remplit pas cette obligation. N. 1119,1120 . 》

Planiol et Ripert, volume 6, no 48, comme:tant l'article 1119 C.N. qui correspond à notre article 1028 c.c. s'expriment en ces termes:

$\ll \ldots$

Si un contractant a promis en son nom le fait d'autrui, son engagement 
est frappé d'inefficacité absolue, puisqu'il ne s'est engagé à rien personnellement et que d'autre part le tiers n'a rien promis, ni directement, ni par un représentant parlant en son nom.

La portée pratique de la règle cidessus est considérablement réduite, sinon annihilée par l'institution du porte-fort qui joue un rôle important dans la vie des affaires. »

Ces règles peuvent évidemment être modifiées par législation. C'est ainsi qu'en vertu de la Loi des relations ouvrières, tous les employés d'un patron sont liés, pour tout ce qui a trait aux conditions de travail, par les clauses d'une convention collective conclue entre leur patron et un syndicat reconnu par la Commission des relations ouvrières. Il s'agit donc de savoir si la clause de retenue syndicale invoquée par l'apppelant est une condition de travail au sens de la Loi. Car, dans l'affirmative, cette clause serait légale et tous les employés de la Compagnie $\mathrm{Pa}$ quet, qu'ils soient ou non membres du syndicat, devraient s'y soumettre sous peine de perdre leur emploi. Dans le cas contraire, les salariés auraient le droit de refuser de se conformer à la clause de retenue syndicale.

Ce point a déjà été soulevé. devant cette Cour, dans une cause de Price Brothers \& Company Limited v. Letarte (1953) B.R. 307. Dans cette affaire, deux iuges ont été d'opinion de rejeter l'appel de Price Brothers pour des motifs tirés de l'article 41 a) de la Loi des relations ouvrières. Des trois autres, deux seulement, soient MM. les Juges J.-A. Gagné et Miller Hyde, ont exprimé l'opinion qu'une clause de retenue syndicale était une condition de travail tandis que M. le Juge Barclay a été d'avis contraire. Il s'ensuit que cette Cour n'est pas liée par cet arrêt de Price Brothers v. Letarte et que la jurisprudence n'est pas encore fixée.

A mon avis, l'objet d'une convention collective est de réglementer les relations entre un syndicat et un natron. Or, la clause de retenue syndicale, qui fait l'obiet de la présente cause, a pour but unique de forcer le patron à faire, pour le bénéfice de l'appelant, la perception des cotisations de ses membres, et ne concerne en aucune façon le tra- vail des employés. Dès lors, il s'agit d'une convention qui ne régit pas les relations entre le patron et ses employés mais bien celles du syndicat et du patron. J'en viens donc à la conclusion que la clause de retenue syndicale 2.01 n'est pas une condition de travail au sens de la Loi des Relations Ouvrières.

Je me suis convaincu davantage du bien-fondé de cette proposition en lisant les articles 4 et 9 de la Loi des relations ouvrières. Aux termes de ces dispositions, l'appelant, en obtenant un certificat de reconnaissance syndicale pour représenter les employés de l'intimée et négocier avec leur employeur une convention collective de travail, devenait le représentant de ces salariés et assumait ainsi, à leur égard, les obligations d'un mandataire envers un mandant. Et, en l'absence d'un texte, on ne peut présumer que le législateur, en édictant la Loi des relations ouvrières, ait voulu placer les syndicats dans une position où ils seraient appelés à choisir entre leur intérêt personnel et leur responsabilité envers leurs mandants, car une telle situation serait contraire aux principes juridiques régissant les relations entre mandant et mandataire. A ce sujet, Planiol \& Ripert, Vol. II, No 1446, s'expriment comme suit:

\section{«Actes intéressant personnellement le mandataire: mandats doubles - En principe, le mandataire n'est pas frappé d'incapacité par le seul fait qu'il serait personnellement intéressé à l'acte. Toutefois, il ne peut faire usage de son mandat pour consentir, au nom de son mandant, un contrat obligeant ce dernier envers lui- même, qui y jouerait le rôle de sti- pulant pour son compte personnel et de promettant pour le compte du mandant... »}

Or, aux termes de l'article II de la convention collective, les ouvriers sont tenus de payer une cotisation syndicale comme condition d'embauchage ou de maintien de leur emploi. Il s'ensuit que, dans l'espèce, l'appelant a joué le rôle de stinulant pour son compte personnel et de promettant pour les salariés, ses mandants. En conséquence, le syndicat, pour faire accepter sa prétention qu'une telle clause de retenue syndicale était une condition de travail au sens de la Loi des relations ouvrières, 
devrait démontrer clairement que le législateur, en édictant cette loi, a voulu déroger aux principes de notre droit civil et permettre au mandataire d'insérer dans une convention de travail des clauses qui le favorisent au\% dépens du mandant.

Aussi, je partage l'opinion du Juge de première instance lorsqu'il déclare qu'une telle clause ne saurait avoir d'effet sans l'assentiment individuel des employés ou sans une disposition légale l'autorisant.

Peut-on cependant soutenir, comme le prétend le procureur de l'appelant, que l'intimée s'est portée fort pour ses employés et, qu'en conséquence elle est responsable des dommages lui résultant du fait que 254 salariés ont refusé de se soumettre à la clause de retenue syndicale obligatoire?

Beaudry-Lacantinerie définissent ainsi la «promesse de porte-fort 》 (Tome 12, No 130):

«...Se porter fort ou se faire fort pour quelqu'un, c'est promettre qu'il s'obligera à faire ce qu'on a promis qu'il ferait....»

Or, je ne vois rien dans les termes de la clause de retenue syndicale qui permette d'induire que la Compagnie Paquet ait promis que tous ses employés s'obligeraient à payer une cotisation syndicale. A mon avis, la seule obligation assumée par la défenderesse était de percevoir pour le bénéfice de l'appelant la retenue syndicale, mais seulement en autant que ses employés étaient légalement tenus de la verser ou consentaient volontairement à la payer.

\section{Je confirmerais.}

\section{JUGE OWEN}

The relevant facts are set out in detail elsewhere. On behalf of the employees the Syndicat (Le Syndicat Catholique des Employés de Magasins de Québec Inc., the Appellant herein) made with the employer ( $\mathrm{La}$ Compagnie Paquet Ltée, the Respondent herein) a collective labour agreement containing the following clause:-

\section{“ARTICLE II REGIME SYNDICAL}

2.01 - L'employeur retiendra sur la paie de chaque employé régulier assujetti à la présente convention, une somme égale à la cotisation fixée par le syndicat pour ses membres, et remettra dans les dix (10) premiers jours du mois suivant, au. représentant autorisé du syndicat, le prélèvement ainsi perçu."

The main point in issue is whether or not this clause in the collective agreement is null in so far as the employees who are not members of the Syndicat are concerned.

In virtue of the Labour Relations Act the Syndicat, having been recognized by the Labour Relations Board, had the power to enter into, on behalf of all the employees, a collective labour agreement with the employer. Such agreement is defined by the Act as follows:-

\begin{abstract}
“2 (e) "Collective agreement" or "agreement" means any arrangement respecting conditions of employment entered into between persons acting for one or more associations of employees, and an employer or several employers or persons acting for one or more associations of employers:"
\end{abstract}

The French version is as follows:-

“2 (e) "convention collective" ou "convention" signifie: une entente relative aux conditions de travail conclue entre des personnes agissant pour une ou plusieurs employeurs ou personnes agissant pour une ou plusieurs associations d'employeurs;"

As far as subject matter is concerned the collective agreement is limited to conditions of employment or "conditions de travail". The problem arises as to whether or not clause 2.01 comes within the terms "conditions of employment" or "conditions de travail".

In my opinion it is of no real help in the solution of this problem to attempt to distinguish between the different terms such as "conditions of employment", "conditions de travail", "working conditions", "conditions d'emploi". "labour conditions" and others is which are used in the French or English 
versions of a statute or in different labour statutes. As far as the present problem is concerned the terms are interchangeable.

With respect to the parties involved, sec. 2 (2) of the Labour Relations Act sets out that the collective agreement basically is between employees and employer. The full title of the Labour Relations Act is "An Act Respecting the Relations between Employers and Employees". In considering what is a condition of employment in a collective labour agreement it should be kept in mind that the agreement is intended to be one between employees and employer. The Syndicat or union acts as representative of the employees in negotiating the agreement but is not personally a party thereto.

Clause 2.01 of the collective agreement provides for the deduction by the employer of an amount equal to the union dues from the salary of all employees, whether union members or not, and for payment by the employer of such deductions to the Syndicat. The number of employees covered by the agreement was 607 and of these 254 set forth in writing to the employer that they objected to any such deduction from their wages. These latter employees (with one or two exceptions) were not members of the Syndicat and the Syndicat did ont have any express authority from them to insert such a clause in the collective agreement.

If the proposed deduction from salary is with respect to an established obligation or indebtedness on the part of the employee it may well be that the provision for the payment of such established indebtedness by deductions from salary is merely an incident of payment, dealing with nothing more than the manner of payment which is a matter of relations between the employer and the employee and is therefore a "condition of employment" or "condition de travail" within the meaning of sec. 2 (e) of the Labour Relations Act and constitutes a valid clause in a collective labour agreement.

However, if the proposed deduction from salary is with respect to a contested or disputed obligation on the nart of the employee then the provision for the payment of such contested in- debtedness by deductions from salary is not merely an incident of payment and is not a matter of relations between employer and employee, but is a determination of the merits of a dispute regarding the liability of the employee towards the Syndicat and a matter of relations between the employee and the Syndicat. Such a provision is not a condition of employment or a "condition de travail" within the meaning of sec. 2 (e) of the Labour Relations Act and does not constitute a valid clause in a collective labour agreement.

The Syndicat takes the position that the employees who are not members of the Syndicat are benefiting by its actions and are obliged to contribute to the funds of the Syndicat. This claim of the Syndicat against the non-member employees may or may not be well founded.

If the Syndicat invokes any obligation on the part of non-member employees toward the Syndicat either by contract or by operation of law solely and such employees contest the claim of the Syndicat then the Syndicat must establish such obligation (both the liability and the quantum) on the part of the employees by legal process before turning to the subsequent step of collection.

In the present case however the Syndicat tried to establish the obligation on the part of the non-member employees by a clause in the collective labour agreement.

In the circumstances the clause under consideration (2.01), in so far as it provides that non-member employees must pay an amount equal to the union dues, is not dealing with the manner of payment or relations between ernplover and employee but is dealing with the creation of an obligation to contribute or relations between employee and the Syndicat. Such a provision is not a condition of employment and in a collective labour agreement it is null.

Accordingly I am of the opinion that the Syndicat has not established its title to the money in trust (representing deductions equal to the amount of the union dues made from the salaries of employees who are not members of the Syndicat) which it is seeking to recover.

I would dismiss the appeal with costs. 


\section{JUGE CASEY}

While I am in agreement with the manner in which my colleagues dispose of this appeal I propose to limit my opinion to the needs of the case; in consequence I am compelled to add these few observations.

In seeking the solution of the problem not too much importance should be attached to the almost indiscriminate use in our labour laws of the terms "conditions of employment" and "working conditions". Admittedly these terms can be distinguished and it is evident that they could have been used so as to make one exclude the other. But it is equally clear that no such distinction was made or, in the alternative - and this is born out by section 9 of chapter 163 - that the subject matter of collective agreements includes conditions of both types.

For these reasons and for the purposes of this case at least it can be said that the terms "working conditions" and "condition of employment" may be used interchangeably or, if each is to be given a special meaning, that both are included in the subject matter of collective agreements; that compulsery payroll deduction clauses, relating as they do to the manner of payment and being for that reason conditions of employment, may be inserted in a collective agreement; and finally, that while in certain circumstances such clauses may be open to attack, they can not be struck from a collective agreement on the pretext that they do not qualify as "working conditions".

Hence the problem as I see it is not whether the impugned clause is foreign to the subject matter of collective agreements and for that reason null and void but rather whether in inserting this particular clause in the agreement Appellant exceeded the limited authority enjoyed by it as the bargaining agent of Respondent's employees.

Whatever may be the position of members it is clear that non-member employees have no contractual obligation towards Appelant. Hence if there exists any obligation on their part to contribute to the Union this obligation. since it cannot be created by the collective agreement and since it does not find its source in a contract, must find its origin in the law.

Despite the silence of the special acts it cannot be assumed that the Legislature intended that unions should donate their services to non-member employees. Certainly it would be most unrealistic to contend that the unions, or more accurately their members, must absorb the expenses incurred by the Union in the discharge in the interests of all, of its duties as a bargaining agent. It would be more in conformity with the economy of our law to say that these expenses should be borne by all who benefit by these activities.

But this reasoning, and it seems to be the only one that might justify the inclusion of a compulsory contribution clause, does not lead to the rubber stamping of all conditions purporting to fall within this general type. Failing. the consent, express or tacit, of the employees, the scope of such clauses must be restricted to the reimbursement of the expenses incurred by the Union as a bargaining agent and if their insertion in the agreement is permissible at all it will be because the non-member employees are obliged by law to contribute to the expenses incurred by the Union as their bargaining agent, and on condition that it be in their interest that this method of payment be set up; and perhaps, subject to the further condition that each employee be ont called upon to pay more than his fair share of the total.

In this fashion I come to the clause with which we are concerned and assuming for the sake of this discussion that the obligation to contribute exists and that its discharge by salary deduction is in the interest of the employees, I ask whether on its face the clause is limited to the recovery of such expenses.

To this question a negative answer must be given. The amount of the levy creates the presumption that is goes beyond the expenses that might be receverable by the Union and the manner in which it is set up imposes on Appellant the burden, not discharged of justifying the assessment. Needless to say the clause was repudiated in good time and its validity was a question that Respondent was entitled to raise. 
For these reasons and without closing the door to the possibility that in some cases a clause providing for a compulsory contribution by means of a payroll deduction by non-members to Union expenses might properly form part of a collective agreement, I would dismiss this appeal.

\section{JUGE EN CHEF GALIPEAULT}

Tenant pour bien fondé le jugement de première instance et concourant dans les conclusions de mes collègues, MM. les Juges Hyde et Taschereau, je rejetterais l'appel avec dépens.

\title{
LA CRO EXCÈDE dE NOUVEAU SA JURmICTION DANS LE CAS DE L'AlLIANCe
}

\begin{abstract}
Le juge J.-O.-L. Boulanger, de la Cour supérieure, décide que la Commission de relations ouvrières a outrepassé sa juridiction en rejetant une requête en recertification de l'Alliance des Professeurs catholiques de Montréal sans l'entendre et en accordant un certificat à un nouvel organisme.
\end{abstract}

\section{CONSIDERANT QUE :}

La requérante est une association professionnelle d'instituteurs et d'institutrices laïcs enseignant en français dans les écoles de la Commission des écoles catholiques de Montréal, une des misesen-cause.

Le 12 mai 1944, l'intimée, la Commission des Relations Ouvrières de la province de Québec, décerna à la requérante, selon les dispositions de la Loi des Relations Ouvrières (S.R.Q. 1941 , ch. 162a), un certificat de reconnaissance syndicale constatant qu'elle groupait la majorité des instituteurs et institutrices laïcs de langue française de la Commission des écoles et l'autorisant à fonctionner comme l'agent négociateur de ces personnes auprès de l'employeur.

Le 21 janvier 1949, la Commission des Relations Ouvrières révoqua le certificat ci-dessus mentionné parce que la requérante, le 17 janvier 1949, avait déclaré chez ses membres une grève inter-

(1) Jugement rendu le 9 octobre 1957 par l'honorable juge J.-O.-L. Boulanger, de la Cour supérieure, District de Québec, no 74282 .

L'Alliance des professeurs catholiques de Montréal, corporation légalement constituée en vertu de la Loi des Syndicats professionnels, ayant son siège social en la cité de Montréal, Requérante, vS La Commission de relations ouvrières de la Province de Québec, corporation ayant son siège social en la eité de Québec (et nommément les cina membres de la Commission), Intimés, \& La Commission des Ecoles catholiques de Montréal, l'Association des Educateurs catholiques de Montréal et The Federation of English Speaking Catholic Teachers Incorporated, Mises en cause. dite par la Loi des Différends entre les services publics et leurs salariés (S.R.Q. 1941, ch. 169).

La requérante se pourvut contre cette décision devant les tribunaux et, le 8 juin 1953, la Cour Suprême du Canada déclara qu'en révoquant le certificat de reconnaissance syndicale de la requérante la Commission des $\mathrm{Re}$ lations Ouvrières avait outrepassé sa juridiction et que cette révocation était nulle et de nul effet. Cet arrêt fut confirmé par le Conseil Privé.

Le 28 janvier 1954, fut sanctionnée une loi de la Législature de la province de Québec pour amender la Loi des Différends entre les services publics et leurs salariés en y ajoutant l'article suivant :

«5a. Depuis le 3 février 1944, date de la sanction de la Loi instituant une Commission de Relations Ouvrières, une association qui ordonne, déclare ou favorise, ou dont les dirigeants ordonnent, déclarent ou favorisent, dont les membres font une grève ou une contre-grève interdite par la présente Loi, perd, de plein droit et par le fait même, le droit d'être reconnue et celui d'agir comme représentant d'un groupe de salariés ou d'employeurs selon le cas, au sens de la Loi des Relations Ouvrières.

Toutefois, il est loisible à la Commission de Relations Ouvrières de reconnaître de nouveau, ultérieurement, 